\title{
Morshen, or a Canoe to Eternity ${ }^{1}$
}

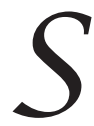

ome poets are astonishingly precocious: Arthur Rimbaud, for example, wrote everything he had to write by the time he was nineteen. Nikolai Morshen's development as a poet offers an opposite example. Gradually maturing in a leisurely and deliberate manner over almost four decades, this poet's work, when viewed in its totality, is a study in ever deepening philosophical thought and ever more finely honed verbal mastery. The stages of Morshen's development and their chronology are obvious enough: the verse of 1936 to 1946 (written prior to Morshen's first published collection and, for the most part, not included in it); the three published books of verse, Tiulen' (The seal, 1959), Dvoetochie (Punctuation: Colon, 1967), and Ekho i zerkalo (The echo and the mirror, 1979); and a few poems that have appeared in émigré journals from his fourth, unpublished collection, "Umolkshii zhavoronok" (The now-silent lark). ${ }^{2}$ To read this poetry in the order in which it was written is to realize that the concept of Darwinian evolution-a major theme in Morshen's poetry-applies not only to the examples of related animal species or related language groups, but also to the model of one man's slowly maturing poetic vision.

Nikolai Nikolaevich Marchenko, who took the German word for "little Blackamoor" as his pen name, was born in Kiev on 8 November 1917, exactly one day after the October Revolution. His mother, Elizaveta Petrovna Toropova, came from a St. Petersburg family of government officials. His father, Nikolai Vladimirovich Marchenko (1887-1969), was

Originally published in Slavic Review 41, no. 1 (Spring 1982): 1-18.

2 See Nikolai Morshen, Tiulen' (Frankfurt am Main: Posev, 1959); Morshen, Dvoetochie (Washington, D.C.: Victor Kamkin, 1967); and Morshen, Ekho i zerkalo (Berkeley: Berkeley Slavic Specialties, 1979). The poems intended for "Umolkshii zhavoronok" appeared in Russkii al'manakh (Paris, 1981), 103-6; and in Perekrestki [Crossroads] 2 (1978): 10-13, 3 (1979): 17-18, and 4 (1980): 27. [Umolkshii zhavoronok was first published in its entirety in 1996; see n. 3 of the following article.-Ed.] 
born in Kazan but grew up and spent most of his life in Kiev, where he studied at the Polytechnic Institute. Strongly drawn to the theater, the senior Marchenko managed to combine teaching mathematics with a career as a stage actor. He fought with General Denikin's forces in the Civil War, was captured by the Bolsheviks, escaped, and managed to return to his double vocation of mathematics and acting. His theatrical activities had to be given up at the beginning of the First Five-Year Plan, when the government banned all private theaters and introduced strict control of the repertoire and acting and directing methods of remaining theaters. After World War II, in emigration, Nikolai Vladimirovich Marchenko found a new calling which brought him considerable recognition in the sixth and seventh decades of his life. He became the novelist and essayist Nikolai Narokov, the author of the novels Mnimye velichiny (translated into English as Chains of Fear) and Mogu (I can) and of short stories and literary essays that appeared in almost all the important émigré journals. Chains of Fear, an in-depth psychological study of life among Stalin's secret police, enjoyed international success and was translated into German and French as well as English. ${ }^{3}$

Some of Morshen's earliest recollections are those of backstage life: rehearsals and performances of plays by Beaumarchais and Ostrovsky and prerevolutionary operettas. The poet remembers reading Pushkin as a child - a traditional, complete Russian edition, of course, which included even the letters-sitting on a sofa piled high with mimeographed play scripts. But he was not personally drawn to the theater, as he was later not drawn to the prose genres, possibly because they were his father's sphere.

At the beginning of the 1930s Morshen witnessed the famine in the Ukraine that was brought about by forced collectivization. Living next to a railroad station, the fifteen-year-old boy could observe nightly the passing freight trains crammed full of peasants being taken to Siberian labor camps. His father was temporarily arrested the same year. To that time the poet dates his realization of the basic inhumanity of the Soviet system, a realization that was later to be reflected in some of his most powerful poems in The Seal.

3 Nikolai Narokov, Mnimye velichiny (New York, 1952). The book is available in English as Chains of Fear, trans. Christopher Bird (Chicago, 1958), in French as Grandeurs imaginaires (Paris, 1959), and in German as Wenn das Salz schal wird, trans. Siegfried von Vegesack (Graz, [1956]). Mogu was published in Buenos Aires in 1965. 
Like most Russian adolescents, Morshen was familiar with the classics of his native poetry, and Derzhavin, Pushkin, and Baratynsky became lifelong favorites. His personal involvement with poetry, however, was the result of a fortuitous accident. Leafing one day through a traditional anthology of popular texts suitable for public recitation, Morshen came upon a poem by Gumilyov. It turned out that a collection of Silver Age poets had been bound together with the anthology, possibly for safety's sake. Gumilyov's "muse of distant journeys," irresistible to the adventurestarved, adolescent mind, infected the young Morshen with poetry. His early love for this secret prince of Soviet poets was later reflected in the Gumilyov citations and reminiscences in The Seal. Eventually Morshen found a group of like-minded coevals interested in reading and, in some cases, writing poetry. In the Soviet Union of 1935 the Silver Age Russian poets (with the exception of Bryusov and Blok, spared because of their political stands at the end of their lives) were banned and generally forgotten. The discovery of Gumilyov led Morshen and his friends to other poets of their parents' generation, resulting in some important rediscoveries.

The earliest verse that has been preserved in the poet's archive is dated 1936. Morshen himself considered his poetry of the years 1936-38 derivative and imitative, "now of Bryusov, now of Balmont, but mostly of Gumilyov." "It is significant that during the period subsequently named after the dreaded secret police chief Ezhov, when the country was terrorized by some of Stalin's worst purges, many young people turned for comfort to Gumilyov's proscribed neo-Romanticism, with its glorification of swashbuckling sea captains and Kiplingesque explorers in Africa. Yet, for all the derivative quality of Morshen's prewar verse, a few poems from that period found their way, in revised form, into The Seal, including some remnants from an extensive cycle of 1938 and 1939 about an unhappy love affair. ${ }^{5}$

Morshen graduated from secondary school in Odessa, where his family had moved in 1933. In 1935 he began his studies at Odessa University, majoring in physics. When his family moved to Kiev, a regulation prohib-

4 Personal communication. A study should one day be written about the phenomenon of the persistent and parallel cults of the three officially disapproved poets in the pre-1960s USSR - the romantic and escapist cult of Gumilyov, the sentimental cult of Esenin, and the intellectual cult of Khlebnikov.

5 See, for example, “Zakaty” [Sunsets], in Morshen, Tiulen', 27-28. See also the untitled poem, ibid., 16 . 
iting transfers of students from one city to another delayed his acceptance at the university there for one year. Consequently, he was still a student at the outbreak of the war and was therefore not drafted into the army. In September $1941 \mathrm{Kiev}$ was occupied by the German army. In February 1942 Morshen married Nataliya Vasilievna Zozulya. The entire family left Kiev at the time of the German retreat, moving first to Königsberg, then to Berlin. The end of the war found them in Hamburg.

Despite the constant threat of forced repatriation (under the terms of the Yalta Agreement, the three Western allies rounded up thousands of natives of Russia all over Germany and handed them over to the Soviet authorities), there quickly arose in the displaced persons camps of West Germany what later came to be called the literature of the Second Emigration. The prospect of writing and publishing without any ideological or stylistic controls must have been intoxicating indeed. In this intellectually stimulating atmosphere Morshen again took up writing poetry, which he had all but abandoned during the war years. In 1946 he made his debut in print, publishing the poem "lskhod" (Exodus; subsequently included in The Seal) in one of the new émigré journals ${ }^{6}$ under the pen name he continued to use. The poem is couched in his somewhat eclectic early manner, but the line "V potok nesushcheisia vselennoi" (Into the stream of the rushing universe-the poet suggests to his companion that they immerse their legs up to the knees in this stream) offers a foretaste of the themes and manner of his second collection, Punctuation: Colon. During the rest of Morshen's stay in Germany, his poetry regularly appeared in émigré periodicals, primarily in the journal Grani (Facets; published in Frankfurt am Main). He supported himself during that period as a laborer in shipyards and in construction work.

In 1950 Morshen and his family left for the United States, an experience he described in the moving poem "Slovno lastochkin khvost, za kormoiu" (Like a swallow's tail, behind the stern). ${ }^{7}$ After brief employment at an automobile plant in Syracuse, New York, Morshen obtained a position as a teacher of Russian in Monterey, California, which he occupied until his retirement in 1977, and settled permanently on the West Coast.

6 This was in a mimeographed edition, of which no copy has been preserved. See "lskhod," ibid., 41.

7 Ibid., 49-50. 
After the grim years of Stalinist terror, after the turmoil of the war and the uncertainties of postwar existence as a displaced person, with its threat of forced repatriation, came a secure and comfortable life by the Pacific Ocean on the Monterey peninsula. Acquiring a home for his entire family (which later also comprised his parents and his aunt), raising his four children, teaching Russian to young Americans, exploring California's mountains, forests, and rivers on long hiking and boating trips with his wife, Morshen must have felt the urge to sum up in poetic form what he had witnessed and experienced in the first thirty years of his life. The result was The Seal, the book of verse in which Morshen found his own poetic voice and attained his full stature as a poet. The collection includes poems written in Kiev, Germany (where the basic theme of the collection had already taken shape), and California. But the book as a whole is focused on the Soviet experience before, during, and after World War II.

The pinniped mammal after which the collection is named (its title has a clumsy sound in Russian and is ambiguous when translated into English) serves as the book's central symbol and provides its keynote. The significance of the seal is explained in the second poem of the book, also entitled "The Seal." university who attends a compulsory meeting where the entire student body is required to approve the death penalty for whomever the government has designated as "enemies of the people" at the latest show trial (the poem is couched in quatrains of traditional Russian rhymed iambic pentameter, but a prose fragment of hackneyed political oratory is brutally wedged into the middle of the first stanza). His eyes lowered, the protagonist of the poem obediently raises his hand with everyone else, "trying to think of nothing." Later that night he wanders in a public park, still trying to keep that afternoon's experience out of his consciousness and forcing himself instead to think of a seal he had read about in his childhood. To survive, the seal has to break a secret breathing hole in a layer of permanently frozen ice.

Ever since Zamyatin wrote his story "The Cave" a few years after the Revolution, Russian writers have repeatedly likened postrevolutionary spiritual and intellectual life to the coming of a new ice age. Morshen

8 Ibid., 10-11. 
narrows this widely used image to the situation of a particular individual in a totalitarian state. He explains that the political poems in The Seal or, more precisely, the poems that deal with the situation of the individual enslaved by the all-powerful machinery of the state, reflect only what the poet himself had felt, seen, or experienced. In this sense much of The Seal is a poetic response to the urge to testify about the nature of the time in which one lives-just as André Chénier's Iambes and Anna Akhmatova's Requiem were testimonies inspired by the same urge. Only very rarely did Morshen permit himself to alter, for artistic reasons, the exact facts of the experience described. Thus, in the poem in which his lyric hero overhears someone whispering a few lines by Gumilyov and realizes that this person must be a kindred soul, Morshen substituted the contextually appropriate lines from Gumilyov's "Fra Beato Angelico" ("There is God, there is the world. They live forever / While human life is instantaneous and wretched") for the Gumilyov poem he actually overheard. ${ }^{9}$

The Seal contains a number of purely lyrical evocations of Kiev and of nature in the Ukraine. The most memorable poems of the collection, however, and the most accomplished technically, are clearly the political ones. In addition to the poem that gave the collection its title, they are " $\mathrm{V}$ chas, kogda solov'iami" (In the hour, when like nightingales), about the suicide of a Ukrainian collective farmer; "Groza proshla" (The storm is over), in which a vividly captured sketch of the Ukrainian landscape serves as the background for a brief glimpse of an aged peasant trudging on foot to the city to see the public prosecutor about someone who has been-apparently unjustly_arrested; and the quite remarkable "Na Pervomaiskoi zhdu tramvaia" (I wait for the streetcar on the Street of the First of May), where the initially realistic sketch of an employee unable to get to work on time because the right streetcar does not come is gradually blown up into a suffocating nightmare about a society in which everyone is at all times presumed guilty by the state (this poem is based on a concrete historical phenomenon, the draconian Soviet law of 1940 that made not only

9 The cited lines from Gumilyov's "Fra Beato Angelico" appear as an epigraph to the untitled poem, ibid., 18, and fragments from these same lines are scattered in the fourth stanza of this poem. Morshen remembers that the Gumilyov lines he actually overheard in the situation described in the poem were from that poet's "Indiuk" [The tom-turkey]. 
absenteeism but also being late for work a state crime). ${ }^{10}$ The powerful psychological impact of "Na Pervomaiskoi zhdu tramvaia" is achieved by relatively simple means: the hypnotic reiteration of the refrain "A streetcar comes, but it's not mine" and the gradual transformation of workaday reality into a Kafkaesque dream from which the narrator is allowed to awaken in the very last line.

Similar poems employ structures of considerable complexity. In "Vecherom 7-go noiabria" (On the evening of the 7th of November"), the loneliness and alienation of the protagonist, unable to participate in the "carefully rationed merriment" that celebrates the October Revolution anniversary, is contrasted with the dance rhythms of "two orchestras playing from three balconies ... for the toiling millions." ${ }^{11}$ The three alternating dance rhythms (a waltz, a polka, and a krakowiak) produce a deliberately discordant effect, oddly reminiscent of the three simultaneous orchestras in the first-act finale of Mozart's Don Giovanni. A further internal contrast is provided by unexpectedly appropriate, ironic quotations from Pushkin's The Bronze Horseman, A. K. Tolstoi, Pasternak, and popular songs. The deliberate clash between a merry dance tune and the tragic theme it expresses is also found in the brief poem "Po tropinke po lesnoi" (Along a forest path), a lament for two soldiers killed in the war which is couched in the rhythm of a boisterous polka. ${ }^{12}$ The hackneyed text of a popular polka with which the poem ends serves as an apt reminder of life's and nature's indifference to individual tragedy and loss.

The most densely textured poem in The Seal and one that ushers in the verbal imagination and lexical virtuosity of Morshen's later poetry is "Kak krugi na vode" (Like ripples on water). ${ }^{13}$ Stylistically a bridge between The Seal and Punctuation: Colon, the poem derives its entire imagery from the multiple meanings of a single Russian word, krug. Meaning basically circle, krug can in certain contexts also mean ripples on water, cycle, sphere, circuit, and even nautical life preserver, and Morshen exploits all these meanings. He opens the poem with a picture of pervasive fear, spreading out like ripples on water, filling every nook and cranny, lurking in all dark corners, and even seeping in through the pores of one's

10 Ibid., 15,23 , and 17 , respectively.

11 Ibid., 12.

12 Ibid., 40.

13 Ibid., 19. 
skin. The loner hero, typical of many poems in The Seal, tries to hide from the omnipresent terror within his own four walls:

Дверь на крюк! Но тебе не заклясть свой испуг

Конурою, как норы понурой:

Он порочен твой круг, твой магический круг

Нереальный своей квадратурой. ${ }^{14}$

Other images of enclosing circles follow: a citation of Ecclesiastes 1:6 ("The wind returneth again according to his circuits," which in its biblical formulation is a Russian proverb); the horizon that girdles the city and congeals into an impermeable wall; a life preserver that is so drenched with bitter water that it sinks. The final stanza points out both the cause and the effect of the fear that blankets the country:

А вдали, где полгода (иль более) мрак,

Где слова, как медведи, косматы:

Воркута, Магадан, Колыма, Ухтпечлаг ...

Как терновый венец или Каина знак-

Круг полярный, последний, девятый. ${ }^{15}$

The "words as shaggy as bears" are the names of concentration camps in the arctic regions, whose existence was denied by the Soviet government for decades, but which had been known to most Russians since the 1930s. The rest of the world became aware of them (to the extent that it ever did) with the publication of Aleksandr Solzhenitsyn's Gulag Archipelago. Morshen was spared the central experience of Solzhenitsyn's life, but the poem just described shows that he realized the cardinal importance of the concentration camp experience for the mentality of homo sovieticus. The Seal was published a few years before Solzhenitsyn's first novel made its sensational appearance. For all the obvious differences in the two writers' personalities and their respective literary genres, Morshen's first book

14 "Latch your door! But you won't exorcise your fright / With this cubbyhole as depressing as a burrow: / Your magic circle is a vicious circle / Because its squaring is unreal." Ibid.

15 "And far away, where the darkness lasts half the year or longer / There are words as shaggy as bears: / Vorkuta, Magadan, Kolyma, Ukhtpechlag ... / Like the crown of thorns or the mark of Cain - / The polar circle, the ultimate, the ninth one." Ibid. 
often explores in the lyrical mode experiences remarkably similar to those Solzhenitsyn's novels probe. The parallels extend from the obvious ones, such as the evocation of Dante's circles of hell when writing of the labor camps and Nerzhin's determined effort to keep his prohibited volume of Esenin (just as Morshen's lyric hero hangs on to his Gumilyov quotations), to more complex ones, such as the kinship between the lyrical voice in The Seal and Solzhenitsyn's loner heroes, the Nerzhins and the Kostoglotovs, or the subtle correspondences between the poem "Andreevskaia tserkov"” (St. Andrew's Church) and chapter 23, "The Church of St. John the Baptist," in Solzhenitsyn's The First Circle. ${ }^{16}$ These parallels, which would make a fitting subject for a separate study, are neither accidental nor the result of any possible mutual influence. Morshen simply has the same remarkable ability to bring into focus the essential core of Soviet experience that Solzhenitsyn had so admirably manifested in another literary medium.

In his introductory essay to The Seal, Vladimir Markov justly wrote that this was "poetry of high quality, unfeigned modesty, unostentatiously independent in its themes and its choice of artistic means," containing "keen thinking, internal logic, and, at times, exciting play of semantic contrasts and viewpoints." ${ }^{17}$ The publication of The Seal placed Morshen's name in the forefront of Russian émigré poetry, and it must have also initiated his present high reputation among underground poetry lovers in the Soviet Union. Like any poet who had found his true voice and discovered his particular subject matter, Morshen might have gone on exploring this successfully inaugurated manner. Instead, he turned to entirely new themes and evolved a fresh poetic manner for dealing with them in the poems that comprise his second published collection, Punctuation: Colon. ${ }^{18}$

In the late 1950s there occurred an important shift of perspective in Morshen's poetry. Until then his poetry had been concerned with the experiences of a particular person in a particular country during a clearly delimited period in history. Now the poet's vantage point soared upward. His horizon expanded vertiginously. His vision encompassed both minute close-ups and cosmic vistas. Even his literary and intellectual genealogy

16 Ibid., 26 and Aleksandr Solzhenitsyn, V kruge pervom (New York, 1968), 112-18.

17 Morshen, Tiulen', 3-4.

18 Dvoetochie was reviewed by SK in Novyi zhurnal, no. 88 (1967): 297-99. The present essay is an elaboration and extension of his readings of Morshen's poetry in the review.-Ed. 
underwent a metamorphosis, so that a quarter of a century after he began writing verse, Morshen suddenly acquired a new set of literary predecessors and-impossible as it may sound in biological terms-changed his intellectual ancestry.

The beginning of this inner transformation coincided roughly with the publication of Pasternak's Doctor Zhivago and the ensuing controversy of l'affaire Pasternak. During approximately the same period, Morshen, like a number of others in the West who were concerned with modern Russian poetry, rediscovered Osip Mandelstam and became newly aware of the significance of Nikolai Zabolotsky. As Morshen recalls it, he was familiar with the work of Pasternak, Mandelstam, and Zabolotsky while he was still in the Soviet Union, but it was at this particular juncture in his life that all three began exercising a powerful influence on his own work. The congenial elements that Morshen found in Pasternak's joyous precision, Mandelstam's transfigured lucidity, and the later Zabolotsky's life-affirming pantheism brought to his own writing a new and, on the whole, more optimistic conception of the tasks and functions of poetry.

His continuing interest in new developments in the physical and biological sciences led Morshen to discover the philosophy of Pierre Teilhard de Chardin. In the writings of the author of The Phenomenon of Man, Morshen found a convincingly argued verification of some of his own poetic intuitions. He was attracted not so much by Teilhard's ingenious synthesis of Christian theology and Darwinian evolution as by his powerful arguments for the teleological aim of this evolution, for the inevitable spiritualization of the cosmos through the agency of humanity. To a mind that has experienced firsthand the totalitarian dehumanization of society, the Teilhardian noosphere is understandably more attractive as the next stage in our development than the soulless anthill or termites' nest to which Marx, Lenin, and Mao have so resolutely condemned us. In Teilhard's long-range view, the horrors and cruelties of our century take their logical place in the long line of atrocities that humanity has been periodically inflicting upon itself in the course of its tortured but irreversible progress.

The cross-fertilization of Morshen's poetry by the philosophy of Teilhard is comparable to nineteenth-century symbiotic relationships between Schelling and Tyutchev and between Schopenhauer and Fet. Just as Schelling's thought revealed to Tyutchev his "heavenly vault ablaze with stellar glory" ("nebesnyi svod, goriashchii slavoi zvezdnoi”), Teilhard 
and, before him, the new discoveries of twentieth-century physical and biological sciences opened up for Morshen new perspectives both for humanity's future and for poetry. The tradition of finding poetic inspiration in the realm of the exact sciences goes back to Lomonosov in Russian poetry, but it fell into disrepute in the nineteenth century-one can mention the total contempt in which such figures as Gogol and Lev Tolstoi held scientific disciplines based on precise observation and direct study of nature. In more recent times, however, Chekhov, Nabokov, and Solzhenitsyn were led by their involvement with the exact sciences to new avenues of literary expression. In poetry, Osip Mandelstam, with his genuine interest in Linnaeus and Lamarck, ${ }^{19}$ and Nikolai Zabolotsky, whose poetry moved from benign Khlebnikovian pantheism to a troubled examination of man's relationship to the rest of the universe, offer clear precedents for some of Morshen's concerns in his second collection.

The harsh, restricted, and congealed universe of The Seal opens up in Punctuation: Colon into the cosmos and nature, of which humanity is but a component part. The hopeless loner who was the lyrical voice of the first book is now the proud descendant of magnificent evolutionary processes and the ancestor of godlike beings of the future in whose minds time and space will be transformed in ways we cannot imagine. ${ }^{20}$ The poet has not forgotten that police states and concentration camps are still a part of our reality; but it is equally a part of his—and our-reality that "Amidst the universal silence / Sharing its suffering with no one / The Earth flies, whirls, sings / Enveloped in the haze of the Word." ${ }^{21}$

19 Mandelstam's interest in Linnaeus, Lamarck, Buffon, and other eighteenth-century predecessors of Darwin's ideas on evolution runs like a constant thread through his Journey to Armenia and also finds expression in his poems "Lamarck" and "A nebo budushchim beremenno ..." [And the sky is pregnant with the future ...]. See Osip Mandel'shtam, Sobranie sochinenii, 3 vols. (Washington, D.C., 1967-71), 2:137-76, $1: 177-78$, and 1:145-47.

20 "Klubilis' nochi u reki," in Morshen, Dvoetochie, 18-19. The poem has been translated into English with miraculous precision by Richard Wilbur as "Nights rolled upon the river's face," TriQuarterly, no. 28 (Fall 1973): 426-27; reprinted in The Bitter Air of Exile, ed. Simon Karlinsky and Alfred Appel, Jr. (Berkeley: University of California Press, 1977), 334-35.

21 Среди молчанья мирового,

Ни с кем страданья не деля,

Летит, кружит, поет Земля,

Окутанная дымкой Слова. (Morshen, Dvoetochie, 10) 
The frightened, hunted animal that served as the central image in The Seal is replaced in Punctuation: Colon by the image of a plant that confidently germinates and grows amidst adverse conditions. The plant imagery of Punctuation: Colon operates on various symbolic levels: the wisdom and harmony of recurrent natural processes, as contrasted to the shoddiness and clumsiness of human politics and history, or the triumph of the forces of life over inert matter. ${ }^{22}$ Above all, the growing plant is Morshen's symbol for the inexorable striving of art and the human spirit for freedom:

В мире тусклых надежд и бездомных собак
По утрам расцветают цветы.
И встает Будапешт. И ведет Пастернак
Разговоры с бессмертьем на ты.

Возникают живые как ртуть полыньи.

Собираются в строчки слова.

Загораются солнца. Гремят соловьи.

И асфальт разрывает трава. ${ }^{23}$

In a letter of 3 November 1888 to his friend Aleksei Suvorin, Anton Chekhov pointed out the similarity of the basic laws that govern natural processes and artistic creation: "We know that nature has a, b, c, d, do, re, $\mathrm{mi}$, fa, sol, and curves, straight lines, circles, squares, green, red, blue. We know that all this in a given combination will yield a melody or a poem or a picture, just as simple chemical elements in a given combination yield a tree or a stone or the sea, but all we know is that they are combined; yet the principle according to which they are combined is concealed from us. Anyone who is at home with the scientific method senses intuitively that a piece of music and a tree have something in common and that both one and the other are created in accordance with identically regular and simple laws. Hence the question of what these laws are." ${ }^{24}$ But Chekhov

22 See "Urok botaniki" [Botany lesson], ibid., 61-62; “Tsvetok" [The flower], ibid., 63-64; and "Bylinka" [A blade of grass], ibid., 58.

23 "In the world of dim hopes and homeless dogs / Flowers blossom every morning. I And Budapest rises. And Pasternak conducts / Informal conversations with immortality. // Unfrozen water, alive as quicksilver, bursts through ice. / Words gather into lines. / Suns blaze forth. Nightingales thunder. / And grass tears up asphalt." Ibid., 43.

24 A. P. Chekhov, Sobranie sochinenii, 12 vols. (Moscow-Leningrad, 1960-64), 11:281. 
was critical of attempts by his contemporaries Boborykin and Merezhkovsky to devise a quasi-scientific "physiology of creativity," feeling that such a project was beyond human capabilities, given the current state of scientific knowledge. He did, however, see a possible approach to the problem by means of intuitive speculation: "the philosophy of creativity."

One of Morshen's central insights in Punctuation: Colon (and in some poems in The Echo and the Mirror) is that creative imagination is just as much a part of nature as organic life and inorganic matter:

\author{
Ударят трижды в берег воды, \\ И трижды крикнут петухи, \\ Что нужно ждать к зиме приплода, \\ Что люди, звери и стихи- \\ Все братья, все одной породы, \\ Не прихоть-но закон природы, \\ Ее успехи, не грехи. ${ }^{25}$
}

The idea of nature becomes basic to Morshen's poetry, beginning in Punctuation: Colon. His nature is not merely lyrical, but is also humanized, endowed with morality and sentiments, and at times frankly allegorical. Contemplation of a sunset on the seashore in "Na zakate" (At sunset) becomes a meditation on the enslavement of Russian literature by opportunistic windbags, with the moon cast in the unexpected role of a fat-faced liar and the phosphorescence of the sea serving as the faithful memory of the past. ${ }^{26}$ Other seascapes in the book provide the poet with intimations of spirituality, with images of cosmic slaughter and of his own unity with the universe. ${ }^{27}$ Seasons, rivers, mountains, and plants are all equally spiritualized and given human significance. The poet of Punctuation: Colon is very much aware of the tragic aspects of existence-he is anything but a Pollyanna-and in at least one poem of the collection he admits that

25 "Thrice will the waters strike the shore, / And thrice will the cocks crow, / That new offspring is to be expected by winter, / That beasts, people and poems / Are all brothers, all of the same race, /Not nature's whim, but her law. / Her successes, not her sins." "U slovarei" [At the dictionaries], in Morshen, Dvoetochie, 30.

26 Ibid., 43-44.

27 "Noch' na vzmor'e" [Night at the seaside], ibid., 52; "More, kholodnyi perpetuum mobile" [The sea, a cold perpetuum mobile], ibid., 48; and "Segodnia tikho na more" [The sea is quiet today], ibid., 54 . 
mankind just might turn out to be too self-destructive to survive. ${ }^{28}$ But he also knows that limitations can again and again be overcome against impossible odds, whether by flying fish escaping their native element, a Mesozoic saurian becoming the ancestor of a present-day mammal named Nikolai Morshen, a blade of grass growing through the asphalt, or the poetry of Osip Mandelstam surviving government-decreed destruction and winning a huge new audience.

Hand in hand with the poet's confidence in the higher cosmic order goes his confidence in the power of the human imagination and the ability of language to express what the mind and spirit perceive. This is the message of Morshen's witty poem "Otvet na notu" (Reply to the note), ${ }^{29}$ a deliberate challenge to one school of Russian émigré poetry with its obligatory existential despair, mistrust of verbal virtuosity, and negation of the ability of language or literature to communicate anything at all, as expressed in the famous maxim "Esli nado ob"iasniat', to ne nado ob"iasniat"' (If you need to explain it, it's not worth explaining). In Morshen's view, this so-called Paris Note is "poetry's capitulation in the face of what is obvious (for shame!), / in the face of what is known in advance." ${ }^{30}$ Morshen, on the contrary, is a poet who believes in what he has to say and sees nothing wrong in saying it with verve, brilliance, and maximal use of all the resources of the Russian language and poetic tradition. His deep roots in his native language and culture are evident not only in those poems of Punctuation: Colon that meditate on linguistic and poetic topics, but in the elaborate system of references, reminiscences, and direct quotations of Russian proverbs and poets sprinkled throughout the book. The high point of such "collage poetry" (a device Morshen shares with one of the leading Paris Note poets, Georgy Ivanov, with whom he otherwise has little in common) is the finale of the poem "Ia svoboden kak brodiaga" (I'm as free as a tramp). ${ }^{31}$ In this handsome tribute to the landscape and nature of his adopted country, Morshen has the weeds and grasses of the North American wilderness sing a ten-line rhymed song made up entirely of cited lines of Pushkin, Khomyakov, A. K. Tolstoi, Fet, Blok, and other Russian poets.

\footnotetext{
28 "Balerine" [To a ballerina], ibid., 47.

29 Ibid., 31-32.

30 Ibid., 32.

31 Ibid., 65-66.
} 
One seemingly paradoxical aspect of Morshen's poetry is its combination of extremely modern themes and thought with traditionalist external form. His poetry up to and including Punctuation: Colon is all couched in traditional Russian syllabotonic meters and exact, nineteenth-century-type rhymes. In this respect, Morshen is comparable to two modern American poets, Robert Frost and Richard Wilbur (his inner correspondences with and similarities to the latter extend beyond matters of poetic technique, and it is only fitting that Morshen and Wilbur translated each other's poetry). However, if we remember that the contemporaries of Johann Sebastian Bach considered him an outmoded composer who had fallen behind the times technically, we can see that it is dangerous to make pronouncements on an artist's modernity on the basis of his technique alone. Besides, as Vladimir Weidlé has perceptively pointed out, Morshen's meters sound far from standard when applied to his themes and outlook: "There is a particular metrical vigor (stikhotvornaia bodrost') in this and his other poems, which the poets of recent decades either avoided or simply lacked. It is hard to define it; it is as if they failed to add lemon peel to certain bitter drinks. Morshen's poems have it. It can be smelled in his iambic tetrameters and therefore he need not be embarrassed of them." ${ }^{32}$

After the publication of Punctuation: Colon, there came a new turn in Morshen's poetry, the nature of which was not at first apparent even to his more attentive readers. He had always been concerned with verbal textures and sonorities, but his poems that appeared in Novyi zhurnal from about 1970 on and that were eventually incorporated in The Echo and the Mirror acquired such textural density that individual lines at times sounded like several lines of verse collapsed or telescoped into one. Where the poems of Punctuation: Colon found new perspectives and new solutions to the eternal problems of nature, art, and man, the poems of the next book seem actually to fuse these three categories into one unity. The agency of this fusion is Morshen's exploration of lexical devices not usually associated in recent times with serious (let alone philosophical) poetry: onomatopoeia, paronomasia, anagrams, and puns. This entire area of language had, of course, been explored with great thoroughness earlier in the twentieth century by Russian Futurist poets, especially Khlebnikov, Mayakovsky,

32 Vladimir Veidle, “Zhretsy edinykh muz: 7. Dvoe drugikh,” Novoe russkoe slovo, 28 October 1973. 
and Kruchyonykh, and, in her own somewhat different manner, by Marina Tsvetaeva. Of the many words used to describe the phenomenon, Aleksei Remizov's term "verbalism" is perhaps the most suitable.

Yet, Morshen's new verbalism is different in kind from Khlebnikov's or Tsvetaeva's. Their usage of it was Dionysian and intuitive, his is Apollonian and filtered through a mind versed in mathematics, cybernetics, and modern probability theory. It would be wrong to apply the term "experimental" to Morshen's later poetry, because, as Leonid Rzhevsky has pointed out, "his discoveries in this area are so unique and significant in their richness and their striving to fuse the sound and the sense" that they are "no longer a game but a fulfillment." Rzhevsky goes on to say that Morshen's new fusion of sonority and meaning is "structurally perfect and harmonious" and that it derives "from euphony and from philosophic meditations and from Pasternak and from Khlebnikov, but most of all from the exceptional talent of the poet himself." ${ }^{33}$

By adapting the Kruchyonykh-Khlebnikov term for metalogical or trans-sense language, zaum', to his own usage (in one poem he makes it an anagram for $m u z a$, muse, and in another draws a witty parallel between zaum', Kruchyonykh's famous dyr bul shchyl, and the Einsteinian formula $\mathrm{E}=\mathrm{mc}^{2}$ ), Morshen acknowledges his debt to his predecessors in Russian verbalism. On the one hand, he is more conservative than these predecessors, because he keeps his verbalist explorations within the confines of traditional meters and rhymes (his poems and passages in free verse are few and exceptional). On the other hand, he often goes beyond his predecessors by making his meaning depend on anagrams and palindromes (as in "Pereverten"” [Changeling, or Palindrome], his ironical epitaph for Ilya Erenburg), ${ }^{34}$ by introducing mathematical formulas into his text, and by resorting to a kind of cloning, whereby a poem is split into two or three connected poems while retaining its overall identity as a poetic unit. Morshen has coined the terms $d v u s t i k h$ (double poem) and tristikh (triple poem) to describe such multiple poems. Some of them are connected by having the rhyming last word or words of one section also serve as the title of the next section. A more complex form of cloning occurs in "Raz-

33 Leonid Rzhevskii, “Strofy i 'zvony' v sovremennoi russkoi poezii,” Novyi zhurnal, no. 115 (1974): 137.

34 Morshen, Ekho i zerkalo, 16. 
dvoiniki" (Split twins), ${ }^{35}$ in which the narrator's separation from his other self and his search for it are graphically represented on the page by the poem's splitting about halfway through into two parallel columns which become two separate poems. The possibility of the ultimate reunion of the two selves is indicated by the final long line printed across the page, which can serve as the last two lines for either one of the two poems that have split off from the poem's beginning.

Morshen, though not ordinarily given to theoretical pronouncements about his work, coined a term to describe his later verbalist and structural procedures: deepodrazhanie. Constructed by analogy with deeprichastie (adverbial participle) and zvukopodrazhanie (onomatopoeia, literally imitation of sound), deepodrazhanie can be approximately translated as imitation of action or imitation of deed. Morshen saw the procedure as an intuitive search for meaning based not on verbal stems (as had been the case with both Khlebnikov and Tsvetaeva), but on chance and intuition. The object of the search is to have the words both speak the poem's meaning and perform this meaning for the reader. Morshen's continuing involvement with Teilhard de Chardin and with modern physics and cybernetics convinced him that a teleological approach to existence is possible and that profound insights can be arrived at through seemingly absurd and aimless paths. If such things as the mechanism of the subconscious, intuitive insight, and even the laws of evolution are operative in the progress of the exact sciences (as illustrated for Morshen by Arthur Koestler's account in his Sleepwalkers of the fumbling and devious methods by which Copernicus, Kepler, and Galileo gradually unraveled the mysteries of the solar system), ${ }^{36}$ they should all the more be the province of the poet and of poetry.

This entire complex of ideas informs Morshen's poetry with its overall confidence in life and in the ultimate aims of mankind, a confidence that is highly unusual in émigré poetry and one which Weidlé described in a slightly different connection as the presence of lemon peel in Morshen's poems. On the personal plane, this confidence is further justified by the symbiotic relationship between Morshen's poetic evolution and his continued residence in Monterey. He has always loved boating and hiking in

35 Ibid., 35.

36 Arthur Koestler, The Sleepwalkers: A History of Man's Changing Visions of the Universe (New York, 1959). 
the woods and has always connected these activities with poetry. Fishing from a boat in the Pacific Ocean, canoeing on California's rivers, and exploring its forests and mountains, he feels, provide him with the themes of his poems and determine their forms. ${ }^{37}$

The third collection of Morshen's poems, The Echo and the Mirror, comprises his output between about 1967 and 1974. In a sense, the collection is something of a synthesis between The Seal and Punctuation: Colon. The poems couched in the new deepodrazhanie manner develop brilliantly (and in a hopelessly untranslatable way) Morshen's major theme of the basic unity between language, nature, and art. In a poem that compares a formal garden and a wild forest, Morshen shows the inner logic of the growth of a forest through a graphic device. A jumble of letters yields, on closer examination, first a sentence of prose and then a quatrain of rhymed verse, with the rhymes placed where no one could expect them:

\title{
Однаковнимательныйвзорвнемувидитпрелестьумаистрогостьлюбви
}

Однако внимательный взор в нем увидит прелесть ума и строгость любви.

\author{
Однако внима- \\ тельный взор в нем уви- \\ дит прелесть ума \\ и строгость любви. ${ }^{38}$
}

In the dense poem "Primety" (Omens), ${ }^{39}$ dealing with the providential aspects of Pushkin's death, the names of a large number of animals, hidden within or between the words of the poem, create the additional image of a forest full of lurking creatures.

37 The reader is reminded that SK was writing during Morshen's lifetime (1917-2001). We have chosen not to bring the texts of the four essays about SK's contemporaries, Nikolai Morshen and Valery Pereleshin, into the present.-Ed.

38 "howevertheattentiveglancewilldiscerninitthecharmofintelligenceandtheseverityoflove However, the attentive glance will discern in it the charm of intelligence and the severity of love.

However, the atten-

tive glance will dis-

cern in it the charm of intelligence

and the severity of love." ("Sad i les," in Morshen, Ekho i zerkalo, 23)

39 Ibid., 69-70. 
The practice of deepodrazhanie accommodates Morshen's serious themes, but because it involves puns, it has led, not surprisingly, to some humorous poems-something new in Morshen's poetic practice. Thus, in "Na vystavke" (At the art exhibit), the poet plays with unexpected meanings he gets from dismembering the names of masters of modern painting, while at the same time evoking the lilting tune of the old cakewalk " $\mathrm{La}$ petite Tonkinoise" (known in Russian as "Kitaianochka"). ${ }^{40}$ In "Norma braka" (meaning either The norm of marriage or The norm of rejecting defective goods), the heroine, who is at first equated with the maiden in the peasant song from Evgeny Onegin, Bogdanovich's Dushenka (that is, Psyche), and Blok's girl from the church choir, quickly mutates, in fewer than two lines, via Blok's Beautiful Lady into the Queen of Spades, Chekhov's Lady with the Little Dog, and, most ominous of all, into Gogol's "lady pleasant in all respects." 11

But the new manner can also be used for the grim political themes previously treated in The Seal, which were mostly relegated to the background in Punctuation: Colon. In "Volch'ia vernost" (Wolves' fidelity), ${ }^{42}$ the accumulation of standard epithets and sayings associated with wolves in Russian culture turns the protest against the senseless extermination of these "free stepchildren of the enslaved earth" (the ostensible theme of the poem) into an allegory of a lone-wolf poet, whom the Soviet state also exterminates because it can neither tame him nor teach him to perform tricks. "Ukho i ekho" (The ear and the echo), by simple altering of word boundaries in some standard slogans, reveals the situation the official propaganda hides:

$$
\begin{aligned}
& \text { “На родине-счастье!” } \\
& \text {-Народ ... и ... несчастье! } \\
& \text { “На родине воля!” } \\
& \text {-Народ ... и ... неволя! } \\
& \text { “Коммуну же надо! Ставьте!” } \\
& \text {-Кому ... нужен ... ад ... Оставьте! }{ }^{43}
\end{aligned}
$$

40 Ibid., 12.

41 Ibid., 24.

42 Ibid., 65.

43 “'In our country there's happiness!' / — The people ... and ... misfortune! // 'In our country there's freedom!' / - The people ... and ... captivity! // 'But we need the commune! Build it!' / —Who needs ... [this] ... hell? Let it be!” Ibid., 14. 
The poet of the third volume has the advantage of a greater distance from and a more balanced perspective on Soviet realities than did the poet of The Seal, who wrote from immediate experience. His new perspective is conveyed with tragic honesty and considerable verbal elegance in "V miniatiure" (In miniature), a poem built entirely on the exploration of Russian diminutives. The poet imagines himself leaving the earth, having abandoned his earlier illusions:
И за кормою астрокорабля
Сужается российская земля, Сжимается в земельку и в землицу, На ней мелькают личики, не лица, В журнальчиках хвалебные стишки, Психушки, вытрезвилки, матючки- Язык, и тот стремится измельчиться. ${ }^{44}$

At that distance, all the patriotic and military glories in which the Soviet state takes such inordinate pride look small and insignificant. Even the Russian spirit (russkii dukh) becomes its diminutive and thus comes to mean a bad smell (dushok). All this hardly makes the poet happy:
Ликую? Нет: скорее трепещу.
Мельчаю? Да: я съежиться хочу
И вот уже не с верой в постоянство-
Лишь с родинкой на памятке лечу
В чужбинищу свободного пространства. ${ }^{45}$

Even more daringly challenging to accepted Russian traditions, both prerevolutionary and Soviet, is the poem "Poslanie k A. S." (Epistle to A. S.). ${ }^{46}$ Morshen addresses the epistle to Aleksandr Sergeevich Pushkin,

44 "And behind the stern of the spaceship / The land of Russia narrows down / Compresses itself into a landlet, a land-drop, / On it there flicker facelets, not faces, / Laudatory verselets in teensy journals, / Teensy psychoclinics, tiny sobering-up stations, diminutive obscenities - / Even the language itself strives to be petty." Ibid., 79-80.

"Do I rejoice? No, rather I tremble. / Am I becoming petty? Yes, I want to shrivel / And now, no longer with faith in constancy / But only with a birthmark on a memento [instead of Motherland in memory] I fly / Into the immense alien realm of free space." Ibid.

Ibid., 75-78. 
casting the poem, with sovereign, unselfconscious mastery, in a close approximation of Pushkin's own poetic tone and voice. The subject is Pushkin's contempt for political rights and such issues as freedom from unfair taxation and censorship and for other "vaunted rights," as stated in one of the last poems he wrote, "Iz Pindemonti" (From Pindemonte). On behalf of his own generation of "seals and deer" (tiuleni $i$ oleni; the image of the "deer" refers to the hero of Solzhenitsyn's play Olen' i shalashovka, known in English as The Love Girl and the Innocent), Morshen asks Russia's "national genius" whether such an attitude, given Pushkin's oft-expressed enthusiasm for military glory and nationalistic conquest, might not add up to a "logically consequent [national] vice / Which is of use only to tyrants." The extended middle section of the poem describes a baby deer (a real one this time) encountered in the California woods, which preserves its freedom by risking its life in a perilous escape. Pushkin's concept of "secret freedom," to which Blok appealed in his desperate last poem, is thus brought into contrast with the concrete and genuine freedom won by the American fawn.

At the end of "Epistle to A. S.," Morshen stands on its head the long Russian tradition of civic poetry by mentioning two poets who are not in the same league as Pushkin in terms of their poetic genius, but whose commitment was to actual freedom, not to an illusory "secret" one. These are Ryleev, who lost his life in the Decembrist rebellion, and Ralph Waldo Emerson, whose lines about "the shot heard round the world" from "Concord Hymn" (in Morshen's own rhymed translation) serve as a kind of concluding epigraph to the poem, in juxtaposition with the beginning of "From Pindemonte."

Morshen's ability to challenge the giants of the past and get away with it is further borne out by the remarkable double poem "Al'piiskaia vesna" (Springtime in the Alps), ${ }^{47}$ where a mountain brook is heard by the poet to recite a Russian translation of Goethe's "Über allen Gipfeln," driving home once again Morshen's cardinal theme of the unity of nature and man-made art. Goethe's poem had been previously rendered into Russian by Lermontov (whose version is one of the best-known brief lyrics in the language) and by Annensky. Undaunted, Morshen incorporates into his lovely poem a new version that need not fear comparison with its illustrious predecessors.

47 Ibid., 19-20. 
Like The Seal and Punctuation: Colon, The Echo and the Mirror also has a living being as its presiding keynote image. This time it is Mimus polyglottos, the American mockingbird. The collection opens and closes with poems about the mockingbird, and a veritable aviary of other birds is scattered throughout the rest of the book. The birds of the third collection do not merely survive, like the seal, or triumph over history and inert matter, like the blade of grass in Punctuation: Colon. "Posledniaia lastochka" (The last swallow) ${ }^{48}$ opens for the poet a window into eternity, as other swallows did for Derzhavin, Fet, and Mandelstam. The poet's muse in the poem "Muza" appears to him in a variety of avian guises, including a dove, an eagless, and the firebird and swan princess of Russian folk tales. The poet yearns to possess this bird-woman, by violence if necessary, "So that from her clenched lips / Complaints of verse lines would burst forth / In nightingale whistlings / On dry-storm [literally, sparrow] nights." ${ }^{49}$

It is the mockingbird, however, that emerges as the supreme embodiment of the three highest values in Morshen's poetry: nature, art, and freedom. All art is a form of mimicry; the abilities of the Mimus polyglottos are, like the mirror reflection and the echo, art's counterpart in nature. In the concluding poem of the third collection, "Mnogogolosyi peresmeshnik 2" (Mockingbird 2), ${ }^{50}$ the poet's own path and progress through life are traced in six stanzas, in which the mockingbird impersonates six other birds. Only the nightingale in the second stanza is named outright, its identity further driven home by references to nightingales in Pushkin, Delvig, and the Igor Tale. The rooster in the first stanza, the lark in the third, the siskin in the fourth, and the swallow in the fifth are not named or mentioned. They are recognizable to a person versed in Russian tradition by the quoted phrases associated with them in Russian poetry, folklore, or popular songs. Morshen's new American roots, strongly expressed in the "Epistle to A. S.," are here personified by the bird which the mockingbird imitates in the sixth and final stanza. Its Russian manifestation, grai voronii, belongs to the dawn of the poet's life, a dawn which has

\footnotetext{
48 Ibid., 38-39.

49 Чтоб из губ ее стиснутых

Рвались жалобы строчек

Соловьиными свистами

В воробьиные ночи. (Ibid., 27)

50 Ibid., 89.
} 
fled over the seas (uporkhnula za moria). The impossibility of retrieving one's youth is expressed through the single English word that concludes the poem and identifies the bird, "Nevermore."

It is too early to discuss as a coherent whole the poems Morshen has written since the completion of The Echo and the Mirror. They comprise what he calls a "half-collection" that bears the title "The Now-Silent Lark." The poems continue the manner of The Echo and the Mirror, though in a more subdued mode. The most memorable of these new poems add to Morshen's formula of "poetry equals nature equals poetry" a cozy familiarity with mythology (Greek and biblical) and with classical antiquity. In two hauntingly beautiful poems, "Stikhi i stikhii" (Verses and elements) and an untitled one that begins "V nezhnom plene sladkoi slepoty" (In the tender captivity of sweet blindness), images from Homer, Ovid, and the Book of Genesis serve to attenuate the poet's sense of unity between eternal nature and the imaginative processes of the human mind that produce art. A striking stanza in "Stikhi i stikhii" works the titles of comedies by Aristophanes into a description of the creation of the world:

\section{Гудели ритмы в смутном океане, \\ Текла и пела первая река, \\ Летели, плыли по-аристофаньи \\ Лягушки, птицы, осы, облака. ${ }^{51}$}

These new, mature poems may represent a summary of Morshen's earlier poetry, or they may indicate a turning point in his poetic development. In either case, it is hard to imagine how his future work could surpass the profundity and mastery he has already attained.

Over the years, Morshen has done a considerable amount of literary translation. His numerous translations into Russian of American poets (Emily Dickinson, Robert Frost, Randall Jarrell, Phyllis McGinley) and prose writers (Shirley Ann Grau, Bernard Malamud, John Updike, Eudora Welty, Joyce Carol Oates, Isaac Asimov) appeared in the magazine Ameri$k a$ published by the United States Information Agency for distribution in the Soviet Union. For the same magazine he also translated William

51 "Rhythms hummed in a murky ocean, / The first river flowed and sang, / There flew [or] floated, in an Aristophanian manner / Frogs, birds, wasps, clouds.” (Morshen, "The Now-Silent Lark") 
Faulkner's Nobel Prize acceptance speech, portions of Louis Armstrong's autobiography, and a variety of essays on such diverse subjects as science, architecture, film, and rock music. Unknown to anyone in the United States (where Amerika did not circulate), these translations deserve to be studied by those interested in problems of literary translation. Morshen brings to them the same verbal imagination and lexical resourcefulness we know and admire in his poetry. Two tiny examples will have to serve as evidence of his ability to solve seemingly insoluble translation problems. The title of Pauline Kael's book of film criticism Kiss Kiss Bang Bang was rendered by Morshen as Chmok-chmok, pif-paf. Even more astoundingly, considering the lack of both definite and indefinite articles in Russian, the name of the rock group The Who found its Russian equivalent in Te, kto (The Ones Who).

Not too many years ago, Evgeny Evtushenko came to give a reading on the Berkeley campus. The overflow crowds had to be accommodated by a closed-circuit television hastily installed in an additional auditorium. Nikolai Morshen and his wife sat quietly in the back listening to Evtushenko. Only the faculty of the Slavic department and a few students knew who they were. Watching the ovations for Evtushenko, I tried to think of historical precedents: Faddei Bulgarin's Ivan Vyzhigin, regarded by English and Polish critics of the 1830s, unaware of the prose Pushkin and Gogol were then writing, as the finest Russian novel of the age; American journalists of around 1900 mentioning Anton Chekhov as the man to whom Gorky himself had dedicated a novel; or Osip Mandelstam outside a St. Petersburg movie theater about 1915, lost in the midst of a crowd that hysterically acclaimed Igor Severyanin as the great modern poet. Before too many years pass, Morshen's presence at Evtushenko's recital will take its place within this series of events. 